BUDGETING : Journal of Business, Management and Accounting

Volume 2, Nomor 1, Desember 2020

e-ISSN: 2715-2480

p-ISSN: 2715-1913

DOI : https://doi.org/10.31539/budgeting.v2i1.1233

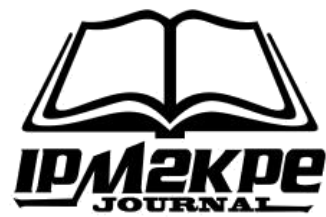

\title{
TINGKAT PEMAHAMAN AKUNTANSI BERDASARKAN KECERDASAN INTELEKTUAL, KECERDASAN EMOSIONAL DAN KECERDASAN SPIRITUAL
}

\author{
Putri Gusti Aulia ${ }^{1}$, Dwi Cahyono ${ }^{2}$, Gardina Aulin Nuha ${ }^{3}$ \\ Universitas Muhammadiyah Jember ${ }^{1,2,3}$ \\ putrigusti1226@gmail.com ${ }^{1}$
}

\begin{abstract}
ABSTRAK
Tujuan penelitian ini adalah untuk menguji pengaruh kecerdasan intelektual, kecerdasan emosional, kecerdasan spiritual terhadap pemahaman akuntansi. Metode yang digunakan dalam penelitian ini adalah metode kuantitatif. Penelitian ini menggunakan data primer dan data sekunder. Jumlah sampel dipilih dengan menggunakan metode purposive sampling yaitu sebanyak 50 mahasiswa Strata Satu (S1) jurusan akuntansi angkatan tahun 2015. Data yang diperoleh kemudian diproses dan dianalisis hanya 50 kuesioner. Metode statistik yang digunakan untuk menguji hipotesis adalah analisis regresi linear berganda. Hasil penelitian ini menunjukkan bahwa secara parsial kecerdasan intelektual, kecerdasan emosional berpengaruh terhadap tingkat pemahaman akuntansi, sedangkan kecerdasan spiritual tidak berpengaruh terhadap tingkat pemahaman akuntansi. Simpulan, kecerdasan intelektual dan emosional berpengaruh terhadap pemahaman akuntansi, dengan begitu semakin baik penerapan kecerdasan intelektual dan emosional maka pemahaman akuntansi juga akan meningkat. Adapun kecerdasan spiritual tidak berpengaruh terhadap tingkat pemahaman akuntansi. Hal ini bisa saja disebabkan karena banyak faktor lainnya tidak teramati dalam penelitian ini.
\end{abstract}

Kata Kunci: Kecerdasan Emosional, Kecerdasan Intelektual, Kecerdasan Spiritual, Pemahaman Akuntansi

\section{ABSTRACT}

The purpose of this study was to examine the effect of intellectual, emotional, and spiritual intelligence on accounting understanding. The method used in this research is quantitative method. This study uses primary data and secondary data. The number of samples selected using purposive sampling method, namely 50 undergraduate students (S1) majoring in accounting class of 2015. The data obtained were then processed and analyzed only 50 questionnaires. The statistical method used to test the hypothesis is multiple linear regression analysis. The results of this study indicate that partially intellectual intelligence, emotional intelligence affects the level of accounting understanding, while spiritual intelligence does not affect the level of accounting understanding. Conclusion, intellectual and emotional intelligence affects accounting understanding, so the better the application of intellectual and emotional intelligence, the understanding of accounting will also increase. Spiritual intelligence has no effect on the level of accounting understanding. This could be because many other factors were not observed in this study.

Keywords: Emotional Intelligence, Intellectual Intelligence, Spiritual Intelligence, Accounting Comprehension 


\section{PENDAHULUAN}

Pengetahuan yang dibutuhkan oleh seorang akuntan menurut hasil evolusi pendidikan terdiri dari pengetahuan umum, organisasi, bisnis dan akuntansi. Untuk memperoleh pengetahuan tersebut, maka pengetahuan tentang dasar-dasar akuntansi merupakan suatu kunci utama, diharapkan dengan adanya dasar-dasar akuntansi sebagai pegangan, maka semua praktik dan teori akuntansi akan dengan mudah dilaksanakan. Namun, kenyataannya pendidikan akuntansi yang selama ini diajarkan di perguruan tinggi hanya terkesan sebagai pengetahuan yang berorientasi pada mekanisme secara umum saja, sangat berbeda apabila dibandingkan dengan praktik yang sesungguhnya yang dihadapi di dunia kerja nantinya. Masalah tersebut tentu saja akan mempersulit bahkan membingungkan mahasiswa untuk mendapatkan pemahaman akuntansi. Dengan demikian tingkat pendidikan di perguruan tinggi masih menunjukkan hasil yang tidak sesuai dengan yang diharapkan. Padahal proses belajar mengajar pada pendidikan tinggi akuntansi hendaknya dapat mentranformasikan peserta didik menjadi lulusan yang lebih utuh sebagai manusia. (Mawardi, 2011)

Faktor-faktor yang berpengaruh terhadap pemahaman akuntansi adalah kecerdasan intelektual, kecerdasan emosional dan kecerdasan spiritual. Menurut Robbin \& Judge (2008) kecerdasan intelektual adalah kemampuan yang dibutuhkan untuk melakukan berbagai aktivitas mental berpikir, menalar dan memecahkan masalah. Melandy \& Aziza (2006) menyatakan bahwa kecerdasan emosional adalah kecerdasan untuk menggunakan emosi sesuai dengan keinginan, kemampuan untuk mengendalikan emosi sehingga memberikan dampak yang positif. Kecerdasan emosional dapat membantu membangun hubungan dalam menuju kebahagiaan dan kesejahteraan. Sedangkan kecerdasan spiritual menurut Wahab \& Umiarso (2011) adalah kecerdasan yang sudah ada dalam setiap manusia sejak lahir yang membuat manusia menjalani hidup penuh makna, selalu mendengarkan suara hati nuraninya dan tidak pernah merasa sia-sia karena semua yang dijalaninya selalu bernilai.

Hasil penelitian Goleman (2012) dan Yoseph (2005) memperlihatkan bahwa kecerdasan intelektual hanya memberi kontribusi 20\% terhadap kesuksesan hidup seseorang. Sisanya, $80 \%$ bergantung pada kecerdasan emosi, kecerdasan sosial dan kecerdasan spiritualnya. Bahkan dalam hal keberhasilan kerja, kecerdasan intelektual hanya berkontribusi $4 \%$. 
Goleman (2012) menyatakan bahwa kemampuan akademik bawaan, nilai rapor, dan prediksi kelulusan pendidikan tinggi tidak dapat memprediksi seberapa baik kinerja seseorang yang sudah bekerja atau seberapa tinggi sukses yang dicapainya dalam hidup. Sebaliknya, seperangkat kecakapan khusus seperti empati, disiplin diri dan inisiatif mampu membedakan orang sukses dari mereka yang berprestasi biasa-biasa saja. Ia juga tidak mempertentangkan kecerdasan intelektual dan kecerdasan emosional, melainkan memperlihatkan adanya kecerdasan yang bersifat emosional, ia berusaha menemukan keseimbangan cerdas antara emosi dan akal. Kecerdasan emosional menentukan seberapa baik seseorang menggunakan keterampilan-keterampilan yang dimilikinya, termasuk keterampilan intelektual. Paradigma lama menganggap yang ideal adalah adanya nalar yang bebas dari emosi, paradigma baru menganggap adanya kesesuaian antara kepala dan hati.

Berdasarkan latar belakang yang telah diuraikan di atas, maka penulis tertarik melakukan penelitian untuk melihat pengaruh kecerdasan emosional, kecerdasan spiritual dan kecerdasan intelektual terhadap tingkat pemahaman akuntansi mahasiswa S1-Akuntansi Perguruan Tinggi di Kabupaten Jember.

\section{KAJIAN TEORI}

\section{Kecerdasan Intelektual}

Istilah intelek menurut Chaplin (1981) berasal dari kata intellect, yang berarti proses kognitif berfikir, daya menghubungkan serta kemampuan menilai dan mempertimbangkan dan kemampuan mental atau intelegensi. Kecerdasan intelektual dalam arti umum adalah suatu kemampuan umum yang membedakan kualitas orang yang satu dengan orang yang lain. Kecerdasan intelektual ini dipopulerkan pertama kali oleh Francis Galton, seorang ilmuwan dan ahli matematika Inggris (Zakiah, 2013). Intelektual adalah kemampuan kognitif yang dimiliki organisme untuk menyesuaikan diri secara efektif pada lingkungan yang kompleks dan selalu berubah serta dipengaruhi oleh faktor genetik. 


\section{Komponen Kecerdasan Intelektual}

Menurut Steinberg (1981) kecerdasan intelektual mahasiswa diukur dengan indikator sebagai berikut: 1) kemampuan memecahkan masalah, yaitu mampu menunjukkan pengetahuan mengenai masalah yang dihadapi, mengambil keputusan tepat, menyelesaikan masalah secara optimal, menunjukkan pikiran jernih; 2) intelegensi verbal, yaitu kosakata baik membaca dengan penuh pemahaman, ingin tahu secara intelektual dan menunjukkan keingintahuan; 3) intelegensi praktis, yaitu tahu situasi, tahu cara mencapai tujuan, sadar terhadap dunia keliling dan menujukkan minat terhadap dunia luar.

\section{Kecerdasan Emosional}

Emosi adalah hal begitu saja terjadi dalam hidup kita. Kita menganggap bahwa perasaan marah, takut, sedih, senang, benci, cinta, antusias, bosan dan sebagainya adalah akibat dari atau hanya sekedar respon kita terhadap berbagai peristiwa yang terjadi pada diri kita. Membahas soal emosi maka sangat erat kaitannya dengan kecerdasan emosi itu sendiri. Emosi merupakan kemampuan seseorang untuk memotivasi diri sendiri, bertahan menghadapi frustasi, mengendalikan dorongan hati (kegembiraan, kesedihan, kemarahan dan lain-lain) dan tidak melebih-lebihkan kesenangan, mengatur suasana hati dan mampu mengendalikan stres.

\section{Aspek-Aspek Kecerdasan Emosional}

Goleman (2012) menyatakan bahwa kecerdasan emosional memiliki lima aspek penting yaitu pengenal diri (self awarness), pengendalian emosi (self regulation), motivasi diri (internal motivation), empati (empathy) dan keterampilan sosial (social skill).

\section{Kecerdasan Spiritual}

Zohar \& Marshall (2001) menegaskan bahwa kecerdasan spiritual adalah landasan untuk membangun IQ dan EQ. Spiritual berasal dari bahasa Latin yaitu spiritus yang berarti prinsip yang memvitalisasi suatu organisme. Sedangkan, spiritual dalam SQ berasal dari bahasa Latin yaitu sapientia (sophia) yang dalam bahasa Yunani berati kearifan. Spiritualitas tidak harus dikaitkan dengan kedekatan seseorang dengan aspek 
ketuhanan, sebab seorang humanis atau atheis pun dapat memiliki spiritualitas tinggi. Kecerdasan spiritual lebih berkaitan dengan pencerahan jiwa.

Orang yang memiliki kecerdasan spiritual tinggi mampu memaknai hidup dengan memberi makna positif pada setiap peristiwa, masalah bahkan penderitaan yang dialaminya. Dengan memberi makna yang positif akan mampu membangkitkan jiwa dan melakukan perbuatan dan tindakan yang positif.

\section{Indikator Kecerdasan Spiritual}

Zohar \& Marshall (2005) menguji SQ dengan hal-hal berikut: 1) kemampuan bersikap fleksibel, yaitu mampu menyesuaikan diri secara spontan dan aktif untuk mencapai hasil yang baik, memiliki pandangan yang pragmatis (sesuai kegunaan) dan efisien tentang realitas. Unsur-usur bersikap fleksibel yaitu mampu menempatkan diri dan dapat menerima pendapat orang lain secara terbuka; 2) kesadaran diri yang tinggi, yaitu adanya kesadaran yang tinggi dan mendalam sehingga bisa menyadari berbagai situasi yang datang dan menanggapinya. Unsur-unsur kesadaran diri yang tinggi yaitu kemampuan menanggapi dan mengetahui tujuan dan visi hidup.

Selanjutnya, 3) kemampuan untuk menghadapi dan memanfaatkan penderitaan, yaitu tetap tegar dalam menghadapi musibah serta mengambil hikmah dari setiap masalah itu. Unsur-unsur kemampuan untuk menghadapi dan memanfaatkan penderitaan yaitu tidak ada penyesalan, tetap tersenyum dan bersikap tenang dan berdoa; 4) kemampuan untuk menghadapi dan melampaui rasa sakit, yaitu seseorang yang tidak ingin menambah masalah serta kebencian terhadap sesama sehingga mereka berusaha untuk menahan amarah. Unsur-unsur kemampuan untuk menghadapi dan melampaui rasa sakit yaitu ikhlas dan pemaaf; 5) keengganan untuk menyebabkan kerugian yang tidak perlu, yaitu selalu berfikir sebelum bertindak agar tidak terjadi hal yang tidak diharapkan; 6) unsur-unsur keengganan untuk menyebabkan kerugian, tidak menunda pekerjaan dan berpikir sebelum bertindak.

Kemudian, 7) kualitas hidup, yaitu memiliki pemahaman tentang tujuan hidup dan memiliki kualitas hidup yang diilhami oleh visi dan nilai-nilai. Unsur-unsur kualitas hidup yaitu, prinsip dan pegangan hidup dan berpijak pada kebenaran; 8) berpandangan holistik, yaitu melihat bahwa diri sendiri dan orang lain saling terkait dan bisa melihat 
keterkaitan antara berbagai hal, dapat memandang kehidupan yang lebih besar sehingga mampu menghadapi dan memanfaatkan, melampaui kesengsaraan dan rasa sehat, serta memandangnya sebagai suatu visi dan mencari makna dibaliknya. Unsur-unsur berpandangan holistik yaitu kemampuan berfikir logis dan berlaku sesuai norma sosial; 9) kecenderungan bertanya, yaitu kecenderungan nyata untuk bertanya mengapa atau bagaimana jika untuk mencari jawaban-jawaban yang mendasar unsur-unsur kecenderungan bertanya yaitu kemampuan berimajinasi dan keingintahuan yang tinggi; 10) bidang mandiri, yaitu memiliki kemudahan untuk bekerja melawan konvensi, seperti mau memberi dan tidak mau menerima.

\section{Pengertian Pemahaman Akuntansi}

Pemahaman akuntansi merupakan sejauh mana kemampuan dalam memahami akuntansi baik sebagai seperangkat pengetahuan (body of knowledge) maupun sebagai proses atau praktik. Penguasaan pengetahuan atau keterampilan yang dikembangkan oleh mata pelajaran, lazimnya ditunjukkan dengan nilai tes atau angka yang diberikan oleh dosen.

\section{Komponen Pemahaman Akuntansi}

Pemahaman akuntansi akan diukur dengan menggunakan nilai mata kuliah Akuntansi yaitu Pengantar Akuntansi, Akuntansi Keuangan Menengah 1, Akuntansi Keuangan Menengah 2, Akuntansi Keuangan Lanjutan 1, Akuntansi Keuangan Lanjutan 2, Auditing 1, Auditing 2, Akuntansi Biaya, Sistem Akuntansi, Akuntansi Manajemen, Akuntansi Sector Public, Sistem Informasi Akuntansi dan Teori Akuntansi. Mata kuliah tersebut merupakan mata kuliah yang di dalamnya terdapat unsur-unsur yang menggambarkan akuntansi secara umum. Tingkat Pemahaman Akuntansi diukur dengan 12 item pertanyaan yang diadopsi dari Zakiah (2013) menggunakan skala likert lima poin. Mata Kuliah tersebut merupakan mata kuliah yang di dalamnya terdapat unsur-unsur yang menggambarkan akuntansi secara umum. 


\section{METODE PENELITIAN}

Penelitian ini menggunakan metode penelitian kuantitatif. Penelitian kuantitatif merupakan metode-metode yang didasarkan pada informasi numerik dan menggunakan analisis-analis statistik yang terdiri dari analisis isi, penelitian survey dan penelitian arsip (Stokes, 2006). Populasi dalam penelitian ini adalah seluruh mahasiswa S1Akuntansi pada Perguruan Tinggi di Kabupaten Jember yang masih aktif. Berdasarkan data yang diperoleh dari Biro Akademik Jurusan Akuntansi di Universeitas Jember, Universitas Muhammadiyah Jember, Institut Agama Islam Negeri Jember dan Sekolah Tinggi Ilmu Ekonomi Mandala Jember dengan jumlah populasi penelitian ialah sebagai berikut:

Tabel 1.

Jumlah Mahasiswa Akuntansi Strata Satu Kabupaten Jember

\begin{tabular}{lc}
\hline \multicolumn{1}{c}{ Perguruan Tinggi } & Jumlah \\
\hline Universeitas Jember & 107 \\
Universitas Muhammadiyah Jember & 190 \\
Institut Agama Islam Negeri Jember & 55 \\
Sekolah Tinggi Ilmu Ekonomi Mandala Jember & 101 \\
\hline
\end{tabular}

Pemilihan sampel pada penelitian ini dilakukan dengan menggunakan purposive sampling, yaitu tipe pemilihan sampel secara acak tidak berdasarkan pertimbangan tertentu yang ditentukan dengan tujuan atau permasalahan dalam penelitian (Indriantoro \& Supomo, 1999).

Kriteria penentuan sampel adalah sebagai berikut: 1) mahasiswa S1 jurusan akuntansi angkatan tahun 2015 yang masih aktif, karena mahasiswa angkatan tersebut sudah mengalami proses pembelajaran yang lama dan saat ini sedang melakukan tugas akhir menjelang kelulusan; 2) telah menyelesaikan mata kuliah Pengantar Akuntansi, Akuntansi Keuangan Menengah 1, Akuntansi Keuangan Menengah 2, Akuntansi Keuangan Lanjutan 1, Akuntansi Keuangan Lanjutan 2, Auditing 1, Auditing 2, Auditing 3 dan Teori Akuntansi; 3) telah menempuh 130 SKS, alasan dari pemilihan sampel ini karena peneliti menganggap mahasiswa tersebut dianggap telah mendapatkan manfaat maksimal dari pengajaran akuntansi dan dapat memberikan umpan balik bagi perguruan tinggi untuk dapat menghasilkan para akuntan yang berkualitas.

Metode pengumpulan data pada penelitian ini dilakukan dengan cara: 1) metode observasi dan menggunakan instrumen penelitian sebagai alat operasionalisasi data konsep menjadi data konstruk untuk menyarin sampel berdasarkan kriteria-kriteria yang 
harus dipenuhi oleh sampel tersebut; 2) wawancara, menurut Sugiyono (2010) wawancara merupakan proses untuk memperoleh data untuk suatu penelitian dengan cara tanya jawab dengan bertatap muka antara penanya dengan narasumber. Dalam penelitian ini, peneliti melakukan wawancara atau survey langsung ke subyek penelitian dengan cara memberikan pertanyaan langsung atau berbicara secara lisan dengan mahasiswa.

\section{HASIL PENELITIAN}

\section{Gambaran Umum Responden}

Berdasarkan data dari bagian akademik, jumlah populasi dalam penelitian ini adalah 451 mahasiswa akuntansi angkatan tahun 2015. Populasi tersebut merupakan mahasiswa Universitas Jember, Universitas Muhammadiyah Jember, Institut Agama Islam Negeri Jember dan STIE Mandala Jember. Dari jumlah keseluruhan tersebut, peneliti menyebarkan kuesioner untuk mendeskripsikan latar belakang responden yang dapat dilihat dari jenis kelamin dan jumlah Satuan Kredit Semester (SKS) yang sudah ditempuh selama mengikuti perkuliahan.

\section{Uji Validitas}

Tabel 2.

Rekapitulasi Hasil Uji Validitas

\begin{tabular}{ccc}
\hline Variabel & Validitas & Keterangan \\
\hline Kecerdasan Intelektual & Valid & \\
Kecerdasan Emosional & Valid & r hitung $<0,05$ \\
Kecerdasan Spiritual & Valid & \\
\hline
\end{tabular}

Berdasarkan tabel 2, dapat diketahui bahwa masing-masing indikator yang digunakan sebagai variabel independen (kecerdasan intelektual, kecerdasan emosional dan kecerdasan spiritual) mempunyai nilai signifikansi $r$ hitung yang lebih kecil dari 0,05. Hal ini berarti indikator-indikator yang digunakan dalam variabel penelitian ini layak atau valid digunakan sebagai pengumpul data. Untuk variabel dependen (pemahaman akuntansi) tidak perlu divalidkan, karena kuesioner merupakan pertanyaan dari hasil mata kuliah yang telah ditempuh mahasiswa angkatan tahun 2015. 


\section{Uji Reliabilitas}

Tabel 3.

Hasil Uji Reliabilitas

\begin{tabular}{lcc}
\hline Variabel & Cronbach's Alpha if Item Delected & Keterangan \\
\hline Kecerdasan Intelektual & 0,898 & \\
Kecerdasan Emosional & 0,919 & Reliabel \\
Kecerdasan Spiritual & 0,923 & $\alpha>0,60$ \\
Pemahaman Akuntansi & 0,881 & \\
\hline
\end{tabular}

Berdasarkan tabel 3, dapat disimpulkan bahwa semua variabel yang digunakan dalam penelitian ini adalah reliabel, karena memiliki nilai cronbach's alpha $(\alpha)$ lebih besar dari 0,60.

\section{Uji Asumsi Klasik}

Uji Normalitas

Tabel 4.

Uji Kolmogorove-Smirnove

\begin{tabular}{ccc}
\hline & Unstandardized Residual & Kesimpulan \\
\hline Kolmogorvre-Smirnov Z & 324 & \multirow{2}{*}{ Berdistribusi Normal } \\
Asymp. Sig. (2-tailed) & 0,05 & \\
\hline
\end{tabular}

Berdasarkan tabel 4, data menunjukan bahwa tingkat signifikansi sebesar 0,324 lebih besar dari taraf kesalahan 5\%. Hasil tersebut menunjukan bahwa data terdistribusi secara normal.

\section{Uji Multikolinearitas}

Tabel 5.

Hasil Uji Multikolinearits

\begin{tabular}{llc}
\hline No & \multicolumn{1}{c}{ Variabel } & VIF \\
\hline 1 & Kecerdasan Intelektual & 1,407 \\
2 & Kecerdasan Emosional & 2,590 \\
3 & Kecerdasan Spiritual & 2,563 \\
\hline
\end{tabular}

Berdasarkan hasil analisis collinearity statistic pada tabel 5, diketahui bahwa dalam model tidak terjadi multikolinearitas. Hal ini ditunjukkan dengan hasil VIF dari masing-masing variabel $<10$. 


\section{Uji Heteroskedastisitas}

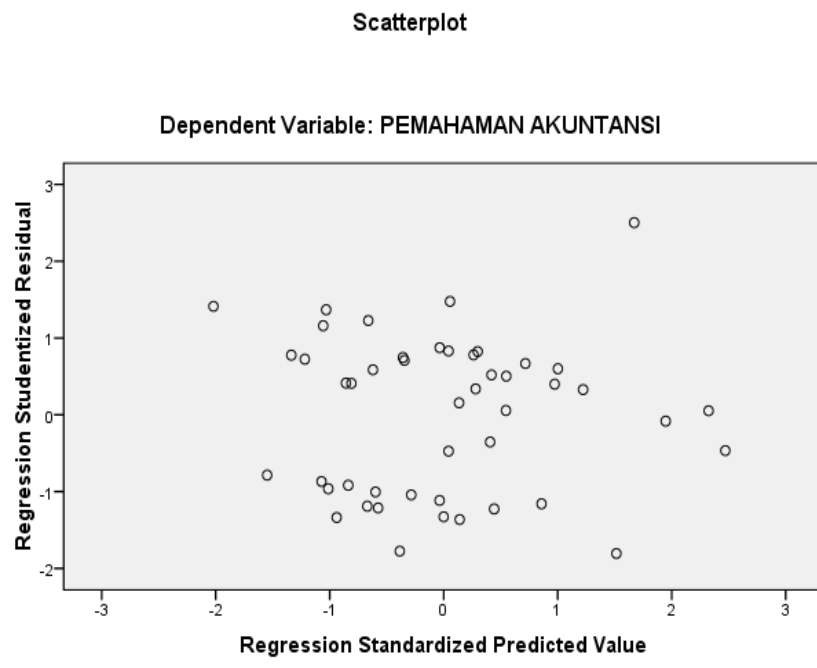

Gambar 1.

Hasil Uji Heteroskedastisitas

(Sumber: Data Diolah Menggunakan SPSS 19, 2019)

Hasil analisis dari grafik Scatterplots pada gambar 1 menunjukkan bahwa titiktitik menyebar secara acak, tidak membentuk suatu pola tertentu yang jelas serta tersebar baik di atas maupun di bawah angka 0 pada sumbu Y. Hal ini berarti tidak terjadi heteroskedastisitas pada model regresi.

\section{Pengujian Koefisien (Regresi Linear Berganda)}

\section{Tabel 6.}

Hasil Regresi Linier Berganda

\begin{tabular}{ccc}
\hline Model & Unstandardized Coefficients & Sig. \\
\hline (Constant) & B & \\
Kecerdasan Intelektual (X1) & 29.610 & .000 \\
Kecerdasan Emosional (X2) & 461 & .008 \\
Kecerdasan Spiritual (X3) & .388 & 019 \\
\hline
\end{tabular}

(Sumber: Data Diolah Menggunakan SPSS 19, 2019)

Berdasarkan tabel 6, dapat diketahui persamaan regresi yang terbentuk adalah:

$$
Y=29.610+0,461 X 1+-0,388 \times 2+0,083 X 3
$$

Keterangan: $\mathrm{Y}=$ pemahaman akuntansi; $\mathrm{X} 1$ = kecerdasan intelektual; $\mathrm{X} 2$ = kecerdasan emosional; X3 = kecerdasan spiritual. 
Berdasarkan hasil persamaan tabel 6, dapat diartikan bahwa: a) konstanta = 29.610, menunjukkan besaran pemahaman akuntansi pada saat kecerdasan intelektual kecerdasan emosioanl kecerdasan dan spiritual sama dengan nol; b) koefisien kecerdasan intelektual $=0,461$, artinya kecerdasan intelektual mempunyai koefisien regresi dengan arah positif 0,461. Jika diasumsikan variabel independen lain konstan, hal ini berarti setiap kenaikan variabel kecerdasan intelektual 1 satuan maka pemahaman akuntansi akan mengalami kenaikan sebesar 0,461.

Selanjutnya, c) koefisien kecerdasan emosional $=-0,388$ artinya kecerdasan emosional mempunyai koefisien regresi dengan arah positif 0,388. Jika diasumsikan variabel independen lain konstan, berarti setiap kenaikan variabel kecerdasan emosional 1 satuan, maka pemahaman akuntansi akan mengalami kenaikan sebesar 0,388; d) koefisien kecerdasan spiritual $=0,083$ artinya kecerdasan spiritual mempunyai koefisien regresi dengan arah positif 0,083. Jika diasumsikan variabel independen lain konstan, hal ini berarti setiap kenaikan variabel kecerdasan emosional 1 satuan maka pemahaman akuntansi akan mengalami kenaikan sebesar 0,083.

\section{Uji Signifikansi Parsial (Uji t)}

Tabel 7.

Hasil Uji t

\begin{tabular}{ccccc}
\hline No & Variabel & t-Hitung & t-Tabel & Keterangan \\
\hline 1 & Kecerdasan intelektual & 2,759 & 2,013 & Berpengaruh \\
2 & Kecerdasan emosional & 2,439 & 2,013 & Berpengaruh \\
3 & Kecerdasan spiritual &,- 521 & 2,013 & Tidak Berpengaruh \\
\hline
\end{tabular}

(Sumber: Data Diolah Menggunakan SPSS 19, 2019)

Berdasarkan nilai statistik hasil analisis pada tabel 7, dapat diketahui bahwa: a) hasil uji parsial kecerdasan intelektual dapat dilihat bahwa nilai t-hitung lebih kecil dari t-tabel $(2,759>2,013)$. Hal tersebut menunjukkan bahwa terdapat pengaruh antara kecerdasan intelektual dengan pemahaman akuntansi. Nilai positif dalam t-hitung mengindikasikan bahwa terdapat hubungan yang negatif; b) hasil uji parsial kecerdasan emosional dapat dilihat bahwa nilai t-hitung lebih kecil dari t-tabel $(2,439>2,013)$. Hal tersebut bahwa terdapat pengaruh antara kecerdasan emosional dengan pemahaman akuntansi. Nilai positif dalam t-hitung mengindikasikan bahwa terdapat hubungan yang positif; c) hasil uji parsial kecerdasan spiritual dapat dilihat bahwa nilai t-hitung lebih kecil dari t-tabel $(-0,521<2,013)$. Hal tersebut bahwa tidak terdapat pengaruh antara 
kecerdasan spiritual dengan pemahaman akuntansi. Nilai negatif dalam t-hitung mengindikasikan bahwa terdapat hubungan yang negatif.

\section{PEMBAHASAN}

\section{Pengaruh Kecerdasan Intelektual terhadap Pemahaman Akuntansi}

Hasil uji regresi menunjukkan variabel kecerdasan intelektual berpengaruh terhadap pemahaman akuntansi dengan koefisien 0,461. Hal ini menunjukkan bahwa semakin baik penerapan kecerdasan intelektual, maka pemahaman akuntansi juga akan meningkat karena kecerdasan intelektual merupakan kemampuan seseorang untuk memperoleh pengetahuan, menguasai dan menerapkannya dalam menghadapi masalah yang dialami. Dengan begitu, faktor kecerdasan intelektual yang diukur melalui kemampuan memecahkan masalah, intelegensi verbal dan intelegensi praktis merupakan suatu faktor yang akan mempengaruhi pemahaman akuntansi. Hal ini sejalan dengan Pasek et al., (2015) yang menemukan bahwa kecerdasan intelektual berpengaruh positif dan signifikan terhadap pemahaman akuntansi.

\section{Pengaruh Kecerdasan Emosional terhadap Pemahaman Akuntansi}

Hasil uji regresi menunjukkan variabel kecerdasan emosional berpengaruh terhadap pemahaman akuntansi dengan koefisien 0,388 . Hal ini berarti dengan semakin baiknya penerapan kecerdasan emosional, maka pemahaman akuntansi juga akan meningkat karena kecerdasan emosional menuntut diri untuk belajar mengakui dan menghargai perasaan diri sendiri dan orang lain serta untuk menanggapinya dengan tepat, menerapkan dengan efektif energi emosi dalam kehidupan dan pekerjaan seharihari. Dengan begitu faktor kecerdasan emosional yang diukur melalui pengenalan diri, pengendalian diri, motivasi, empati dan keterampilan sosial merupakan suatu faktor yang akan mempengaruhi pemahaman akuntansi.

\section{Pengaruh Kecerdasan Spiritual terhadap Pemahaman Akuntansi}

Hasil uji regresi menunjukkan variabel kecerdasan spiritual tidak berpengaruh terhadap pemahaman akuntansi dengan koefisien -0,521 karena t-hitung lebih kecil dari t-tabel. Penelitian ini mendukung hasil penelitian yang dilakukan oleh Dwijayanti (2009) dan Yani (2011) yang menyatakan bahwa kecerdasan spiritual tidak berpengaruh 
terhadap pemahaman akuntansi. Menurut Dwijayanti (2009) hal ini bisa saja disebabkan karena banyaknya faktor-faktor diluar faktor kecerdasan spiritual yang berpengaruh dalam kehidupan individual, misal faktor tekanan mental, lingkungan pergaulan, trauma kegagalan, masalah pribadi, kegiatan diluar kampus (bekerja) pada mahasiswa tersebut. Namun menurut Pasek et al., (2015) kecerdasan spiritual dapat meningkatkan pengaruh kecerdasan intelektual pada tingkat pemahaman akuntansi secara positif dan signifikan jika penerapannya bersama-sama dengan kecerdasan emosional.

\section{SIMPULAN}

Berdasarkan uraian-uraian yang telah diungkapkan pada pembahasan, maka dapat diambil beberapa kesimpulan, yaitu kecerdasan intelektual berpengaruh terhadap tingkat pemahaman akuntansi. Hal ini berarti dengan semakin baik penerapan kecerdasan intelektual, maka pemahaman akuntansi juga akan meningkat karena kecerdasan intelektual merupakan kemampuan seseorang untuk memperoleh pengetahuan, menguasai dan menerapkannya dalam menghadapi berbagai masalah yang dialaminya.

Kecerdasan emosional berpengaruh terhadap pemahaman akuntansi. Hal ini berarti dengan semakin baik penerapan kecerdasan emosional, maka pemahaman akuntansi juga akan meningkat. Hal ini disebabkan karena kecerdasan emosional menuntut diri untuk belajar mengakui dan menghargai perasaan diri sendiri dan orang lain dan untuk menanggapinya dengan tepat, menerapkan dengan efektif energi emosi dalam kehidupan dan pekerjaan sehari-hari.

Kecerdasan spiritual tidak berpengaruh terhadap pemahaman akuntansi. Hal ini bisa saja disebabkan karena banyak faktor lainnya tidak teramati dalam penelitian ini, misalnya tekanan mental, lingkungan pergaulan, trauma kegagalan, masalah pribadi, kegiatan diluar kampus (bekerja), tidak adanya dorongan atau motivasi untuk bertanya jika ada materi atau soal yang belum bisa dimengerti. 


\section{DAFTAR PUSTAKA}

Chaplin, R. (1981). Perkembangan Intelektual Anak. Jakarta: Erlangga

Dwijayanti, P. A. (2009). Pengaruh Kecerdasan Emosional, Kecerdasan Intelektual, Kecerdasan Spiritual dan kecerdasan Sosial terhadap pemahaman akuntansi. Skripsi. Universitas Pembangunan Nasional Veteran Jakarta

Goleman, D. (2012). Working with Emotional Intelligence (Terjemahan Alex Kantjono W). Jakarta: PT Gramedia Pustaka Utama

Indriantoro, N., \& Supomo, B. (1999). Metodologi Penelitian Bisnis untuk Akuntansi dan Manajemen, Edisi Pertama. Yogyakarta: BPFE Yogyakarta

Mawardi, M. C. (2011). Tingkat Pemahaman Mahasiswa Akuntansi terhadap Konsep Dasar Akuntansi di Perguruan Tinggi di Kota Malang. Jurnal Ekonomi dan Bisnis Islam, 8(1), 1-19

Melandy, R., \& Aziza, N. (2006). Pengaruh Kecerdasan Emosional terhadap Tingkat Pemahamanan Akuntansi, Kepercayaan diri sebagai Variabel Pemoderasi. Simposium Nasional Akuntansi IX. Padang

Pasek, N. S., Dwirandra, A. A. N. B., \& Putri, I. G. A. M. A.D. (2015). Pengaruh Kecerdasan Intelektual pada Pemahaman Akuntansi dengan Kecerdasan Emosi dan Kecerdasan Spiritual sebagai Variabel Pemoderasi. E-Jurnal Ekonomi dan Bisnis Universitas Udayana, 4(10), 703-714

Robbin, S. P., \& Judge, J. (2008). Perilaku Organisasi, Buku 2. Jakarta: Salemba Empat Steinberg, A. (1981). Kampanye Politik dalam Praktek. Jakarta: PT. Intermasa

Stokes, J. (2006). How to Do Media and Cultural Studies: Panduan untuk Melaksanakan Penelitian dalam Kajian Media dan Budaya. Yogyakarta: Bentang Pustaka

Sugiyono, S. (2010). Metode Penelitian Pendidikan Pendekatan Kuantitatif, Kualitatif, dan $R \& D$. Bandung: Alfabeta

Wahab, A., \& Umiarso, U. (2011). Kependidikan dan Kecerdasan Spiritual. Yogyakarta: Ar-Ruzz

Yani, F. (2011). Pengaruh Kecerdasan Intelektual, Kecerdasan Emosional, Kecerdasan Spiritual terhadap Pemahaman Akuntansi. Skripsi. Universitas Riau

Yosep, I. (2005). Pentingya ESQ (Emotional Spiritual Quotion) bagi Perawat dalam Manajemen Konflik. Bandung: Universitas Padjajaran

Zakiah, F. (2013). Pengaruh Kecerdasan Intelektual, Kecerdasan Emosional dan Kecerdasan Spiritual terhadap Pemahaman Akuntansi (Studi Empiris Mahasiswa Jurusan Akuntansi Angkatan Tahun 2009 di Universitas Jember). Skripsi. Universitas Jember

Zohar, D., \& Marshall, I. (2001). SQ Memanfaatkan Kecerdasan Spiritual dalam Berfikir Integralistik dan Holistik. Bandung: Mizan Pustaka

Zohar, D., \& Marshall, I. (2005). Spiritual Capital, Memberdayakan SQ di Dunia Bisnis. Bandung: Mizan Pustaka 